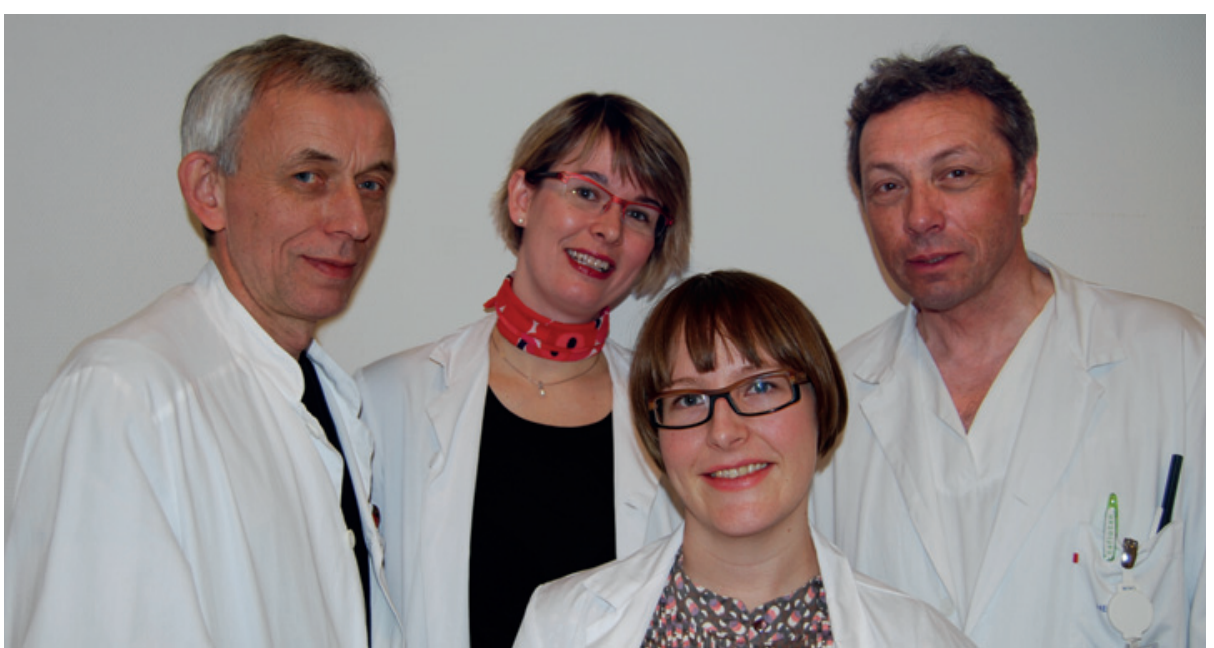

Fire av de fem artikkelforfatterne: Lars Thomassen, Jana Midelfart Hoff, Kristin Modalsli Sand, Eyvind Rødahl. Foto Anette Fromm

MIN FØRSTE PUBLIKASJON

\title{
Synsproblemer etter hjerneslag skal utredes
}

Pasienter med synsfeltutfall etter hjerneslag utredes ikke godt nok.

Dette viser en ny norsk studie.

Rundt $60 \%$ av pasienter med hjerneslag opplever problemer med synet. Det tilsvarer ca. 6000 pasienter årlig i Norge. Det vanligste problemet er synsfeltutfall, hvor deler av synsfeltet faller bort eller blir uklart. Synsfeltutfall etter hjerneslag er assosiert med dårligere rehabilitering, fall, skader og redusert livskvalitet. Pasientene opplever vansker med å orientere seg i rommet og får problemer med å ta seg frem. Å lese avisen eller å se på TV kan bli nesten umulig. Norske retningslinjer for behandling og rehabilitering av hjerneslag (2010) anbefaler at pasienter med synsfeltutfall etter hjerneslag utredes av øyelege med perimetri og henvises til synspedagog for synsrehabilitering.

Blir disse retningslinjene fulgt? Alle pasienter med akutt hjerneslag og synsfeltutfall innlagt ved Nevrologisk avdeling, Haukeland universitetssykehus 2006-09 og registrert i Bergen slagregister, NORSTROKE, ble inkludert (1). Pasientene hadde klinisk synsfeltutfall ved Donders prøve eller hjerneslag $\mathrm{i}$ synsbarken $(\mathrm{n}=353)$. Journalene ble gjennomgått nøye.

- Kun $10 \%$ av pasientene var blitt henvist til synsfeltutredning hos øyelege og kun $2 \%$ var blitt henvist til synspedagog for rehabilitering, sier førsteforfatter Kristin Modalsli Sand. Yngre menn med få nevrologiske utfall etter hjerneslaget ble hyppigst henvist. Graden av funksjonshemning etter hjerneslaget spilte mindre rolle enn forventet. Selv blant pasienter som regnes som funksjonelt uavhengige etter sitt hjerneslag, var kun $25 \%$ blitt henvist til synsfeltutredning.

Synsproblemer etter hjerneslag er et hyppig problem, og vi må bli flinkere til å utrede og rehabilitere disse pasientene. God utredning og rehabilitering er viktig for å bedre utfallet etter hjerneslag og for å øke pasientenes livskvalitet, sier Modalsli Sand.

\section{Forskergruppen}

Artikkelen er skrevet av Kristin Modalsli Sand, Lars Thomassen, Eyvind Rødahl, Halvor Næss og Jana Midelfart Hoff, som alle er tilknyttet Haukeland universitetssykehus. Kristin Modalsli Sand er forskerlinjestudent og ferdig lege i juni 2012. Hovedveileder Jana Midelfart Hoff er overlege ved Nevrologisk avdeling. Lars Thomassen er professor i nevrologi og avdelingssjef for slagenheten ved Nevrologisk avdeling, og Halvor Næss er overlege samme sted. Eyvind Rødahl er professor og overlege ved Øyeavdelingen. Forfatterne er tilknyttet «synsfeltgruppen» som arbeider med synsproblemer etter hjerneslag for å bedre forskningsgrunnlaget på feltet og oversette dette til bedre pasientbehandling.

\section{Erlend Hem}

erlend.hem@medisin.uio.no

Tidsskriftet

\section{Litteratur}

1. Sand KM, Thomassen L, Næss $H$ et al. Diagnosis and rehabilitation of visual field defects in stroke patients: a retrospective audit. Cerebrovasc Dis Extra 2012; 2: 17-23.
Ordforklaringer

Bergen slagregister, NORSTROKE, er et

register over alle slagpasienter som innlegges ved Nevrologisk avdeling, Haukeland universitetssykehus. Registeret omfatter ca. 2200 pasienter.

Synsfeltutfall innebærer bortfall av deler av synsfeltet i begge øynenes synsfelt, enten som bortfall av halve synsfeltet i begge øyne (hemianopsi) eller en kvadrant av synsfeltet (kvadrantanopsi) i begge øynene. Dersom skaden sitter bak synsnervekrysningen, gir det bortfall til samme side på begge øyne. Dersom skaden sitter i synsnervekrysningen, kan man få utfall til hver sin side i hvert øye (f.eks. bitemporalt synsfeltutfall), og dersom skaden sitter foran synsnervekrysningen, kommer synsfeltutfallet i kun ett øye (f.eks. etter sentralvenetrombose).

Synsfeltutredning innebærer en undersøkelse av pasientens synsfelt med perimetri. Ofte brukes autoperimetri som er en automatisert og standardisert undersøkelse. Pasienten blir da stimulert med lysglimt i hele synsfeltet og angir ved å trykke på en knapp når de oppdager stimuli. Man får da et kart over pasientens synsfelt, som viser hvor i synsfeltet pasienten enser stimuli, og hvor vedkommende ikke gjør det.

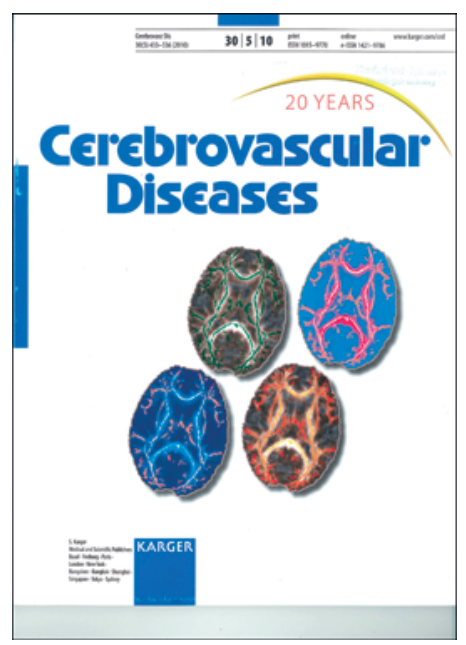

Cerebrovascular Diseases Extra er et nytt e-tidsskrift (www.karger.com/CEE) under hovedtidsskriftet Cerebrovascular Diseases 